\title{
Interpretasi Data Geolistrik dalam Penentuan Keberadaan Rongga pada Pondasi Abutmen dan Pier
}

\author{
Sitti Hijraini Nur \\ Departemen Teknik Sipil, Fakultas Teknik, Universitas Hasanuddin \\ Jl. Poros Malino Km.6, Bontomarannu, Kabupaten Gowa, Sulawesi Selatan 92171 \\ Email: aini_2111@yahoo.com
}

DOI: 10.25042/jpe.052017.05

\begin{abstract}
Abstrak
Proses pemancangan seringkali mengalami kendala dalam mengantisipasi keberadaan rongga ataupun gua dalam tanah yang akan mempengaruhi kegagalan daya dukung friksi atau bahkan kegagalan daya dukung ujung pada tiang pancang. Komposisi batuan yang berada pada pondasi tiang bor dan tiang pancang yang memiliki karakteristik batuan gamping terumbu yang cenderung porous dan berongga perlu mendapat perhatian khusus. Penyelidikan dengan menggunakan geolistrik membantu proses identifikasi secara cepat untuk mengetahui kondisi tanah dan batuan yang berada pada lintasanlintasan tertentu ada posisi pier dan abutmen yang ditengarai menembus lapisan tanah dan batuan berongga dan dikhawatirkan akan berada di lapisan yang berongga atau goa kapur. Pengujian geolistrik dilakukan dengan menggunakan 3 lintasan pengukuran yang masing-masing berada pada lajur centre line, sisi kiri dan sisi kanan grup tiang. Hasil pengukuran disandingkan dengan hasil pengeboran menunjukkan bahwa posisi rencana tiang pancang berdiri pada lapisan tanah dan batuan yang masif dengan komposisi batuan gamping terumbu berselang-seling dengan rekahan dan rongga, clayshell dan marmer atau batuan intrusi yang keras. Sementara rongga dengan diameter yang lebih besar dan terindikasi sebagai goa juga ditemukan pada beberapa tempat di sekitar rencana penempatan tiang bor/tiang pancang.
\end{abstract}

\begin{abstract}
Geoelectric Data Interpretation on Determining the Presence of Cavities on Abutmen and Pier Foundation. The erection piling process is often constrained in anticipating the presence of cavities or caves in the soil that will affect the failure of the frictional bearing capacity or even the failure of the end bearing capacity at the stake.The composition of rocks that are on the foundation of drill piles and others that have the characteristics of limestone reefs that tends porous and hollow need special attention. The investigation using geoelectricity helps the process of rapid identification to know the condition of the soil and rocks that are on certain paths there is a position of pier and abutment which is suspected to penetrate the soil layer and hollow rock and is feared will be in hollow layer or lime cave. Geoelectric testing is done by using 3 measurement paths, each located on the center line lane, the left side and the right side of the pile group. The measurement results coupled with the drill results indicate that the pile plan position stands on soil layers and massive rocks with reef limestone compositions alternating with fractures and cavities, clayshells and marble or intrusive rocks. While the cavity with a larger diameter and indicated as a cave are also found in some places near by the placement plan drill pile.
\end{abstract}

Kata-kunci: Abutmen, daya dukung, geolistrik, goa kapur, pier, rekahan, rongga

\section{Pendahuluan}

Parameter penilaian kualitas jalan selain kondisi fisik yang perlu untuk diperhitungkan adalah kualitas dari prasyarat teknis mencakup kemiringan jalan, sudut tikungan jalan, lebar jalan dan potensi kebencanaan pada jalan tersebut [1].

Kondisi pembangunan jalan layang di daerah batuan karst (batu kapur) memerlukan pemahaman yang lebih dalam sehubungan dengan terdapatnya rongga-rongga dan goa dalam batuan. Berdasarkan hal tersebut, maka perlu untuk dilakukan investigasi geologi yang lebih detail untuk menentukan keberadaan potensi gangguan struktur jembatan tersebut [2].

\section{Metode Pengujian}

Metoda geofisika yang digunakan dalam pengambilan data resistivity adalah metoda geolistrik tahanan jenis 2D. Konfigurasi yang digunakan adalah Konfigurasi WennerSclumberger. Konfigurasi ini tidak terlalu sensitif terhadap adanya perubahan lateral setempat [3, 4], sehingga konfigurasi ini sangat cocok untuk dipakai penyelidikan dalam. Dalam konfigurasi 
ini, jarak antara elektroda arus dan elektroda potensial adalah n kali jarak kedua elektroda potensial. Konfigurasi ini ditunjukkan dalam Gambar 1 dengan dengan faktor geometri sama dengan $\mathrm{k}=\mathrm{p} \mathrm{n}(\mathrm{n}+1) \mathrm{a}$.

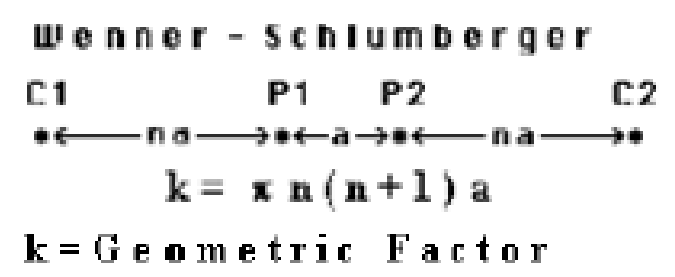

Gambar 1. Konfigurasi pengukuran Wenner Schlumberger

Pengolahan data geolistrik tahanan jenis dalam penelitian ini diawali dengan pengolahan data lapangan. Metoda yang digunakan dalam hal ini adalah perhitungan secara matematis, untuk mendapatkan tahanan jenis semu. Dalam rangka untuk mengetahui model penyebaran resistivitas bawah permukaan di daerah penelitian dilakukan pengolahan data dengan menggunakan perangkat lunak RES2DINV versi 3.54.44. Parameter input program ini adalah resistivitas semu yang telah dihasilkan dari perhitungan data lapangan ditambah dengan data-data pendukung seperti spasi elektroda dan koordinat.

Interpretasi analisa data ini dilakukan dari beberapa data analisa lapangan dalam penampang geolistrik hasil perhitungan secara matematis yang sudah jadi. Hasil interpretasi ini disajikan dalam bentuk penampang tahanan jenis, dan interpretasi geolistrik tahanan jenis, serta peta analisa bidang gelincir dari susunan litologi bawah permukaan di lokasi pengukuran.

Pengolahan data geolistrik tahanan jenis 2D menggunakan program RES2DINV. Hasil pengolahan tersebut berupa penampang dua dimensi yang terdiri dari model tahanan jenis hasil inversi.

\subsection{Keberadaan dan Jenis Gua Kapur (Cavity)}

Cavity merupakan suatu objek yang terdapat dibawah permukaan. Terdapatnya cavity di bawah permukaan merepresentasikan terdapatnya anomali pada subsurface. Cavity atau gua kapur juga bisa disebut sebagai sinkhole [5-7].

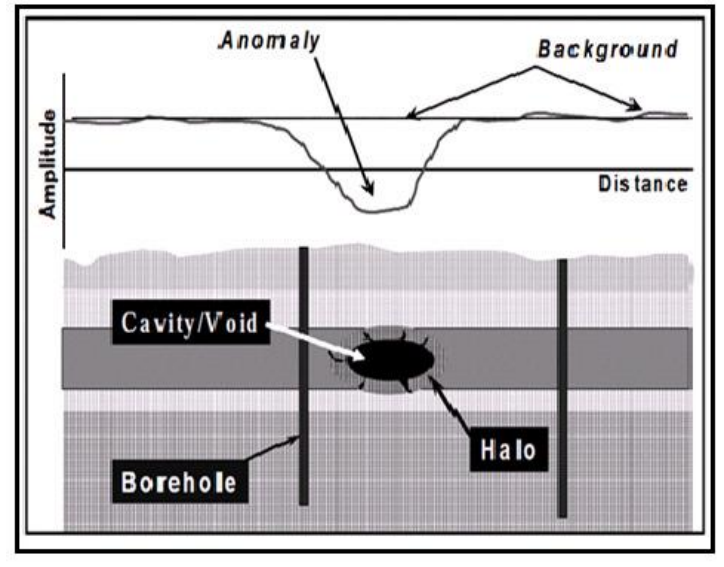

Gambar 2. Ilustrasi sistem cavity di bawah permukaan [8]

1. Sinkholes terbentuk oleh disolusi lambat singkapan batu kapur atau rockhead, dengan runtuhan skala kecil.

2. Keruntuhan sinkholes terjadi oleh kegagalan yang progresif instan di atas gua besar atau sekelompok gua kecil.

3. Caprock sinkholes atau lubang-lubang kecil, menggerogoti dan meruntuhkan caprock larut pada rongga karst di batu kapur yang mendasarinya.

4. Sinkholes dropout terbentuk di tanah penutup kohesif, air hujan yang meresap telah mencuci tanah ke celah stabil dan gua-gua di batu kapur yang mendasarinya.

5. Suffosion sinkholes terbentuk di tanah penutup non kohesif, di mana air hujan yang meresap telah membilas tanah ke celah stabil dan guagua di batu kapur yang mendasarinya.

6. Burried sinkholes terjadi di mana pembubaran atau runtuhnya sinkholes tua diisi dengan tanah, puing-puing atau sedimen karena perubahan lingkungan.

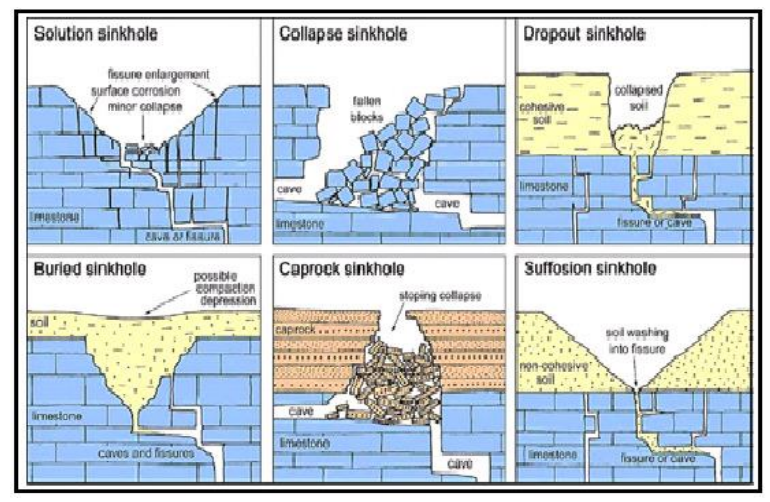

Gambar 3. Klasifikasi sinkhole [8] 


\section{Hasil dan Pembahasan}

Lintasan pengukuran pada lokasi pekerjaan sebanyak 4 lintasan. 3 lintasan memiliki panjang 224 meter yaitu lintasan 7-1-6, 8-5-4 dan 9-2-3. Centre line, yaitu lintasan 10, memiliki panjang 105 meter. Pengukuran dilakukan dari arah Tenggara - Barat Laut seperti terlihat pada gambar berikut:

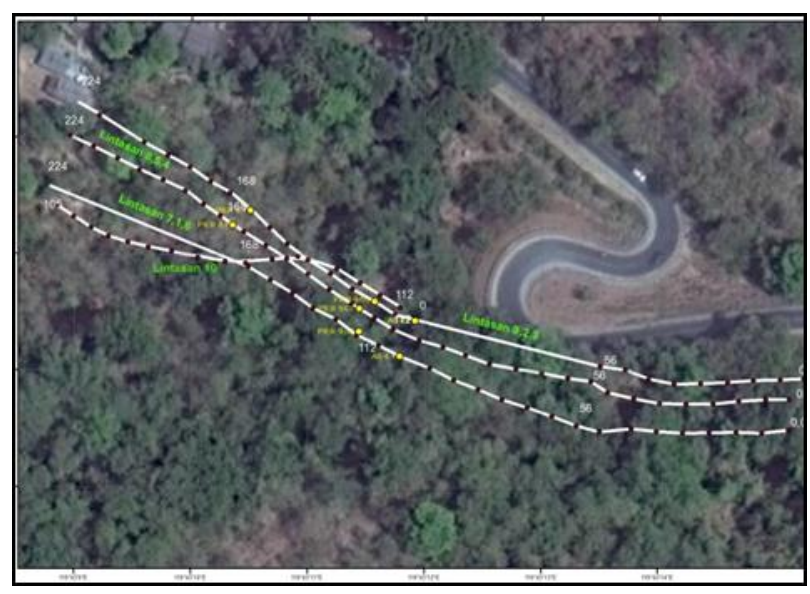

Gambar 4. Lintasan pengukuran

Berdasarkan hasil inversi menggunakan Res2DinV, maka lintasan geolistrik pada lintasan 10 sesuai gambar 4, menunjukkan lintasan 7-1-6 memiliki 5 susunan lapisan yaitu nilai resistivitas 0.00-50 $\Omega \mathrm{m}$ berupa lapisan soil bercampur lapukan batugamping yang terdapat di sepanjang lintasan dengan kedalaman bervariasi mulai dari 0-17 m. Lapisan dengan nilai resistivitas 50-750 $\Omega \mathrm{m}$, diduga merupakan lapisan batugamping terumbu yang masih memperlihatkan adanya rongga yang terdapat pada kedalaman 0-17 m. Lapisan dengan nilai resistivity 750-2000 $\Omega \mathrm{m}$, diduga merupakan lapisan batugamping yang lebih kompak (massive) yang terdapat pada kedalamaan 7-17 m. Lapisan dengan nilai resistivity 750-1500 $\Omega \mathrm{m}$ diduga merupakan rekahan (void/goa) batugamping [9] dengan ukuran sekitar lebih dari 2 meter. Lapisan dengan nilai resistivity $\geq 2000 \Omega \mathrm{m}$, diduga merupakan lapisan batuan keras berupa marmer atau batuan intrusi dengan kedalaman lebih dari $14 \mathrm{~m}$.

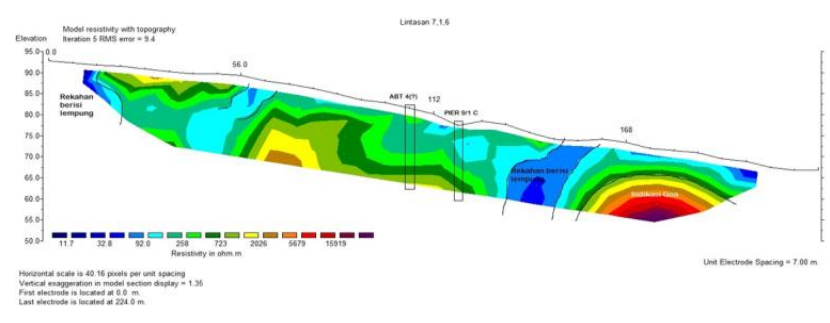

Gambar 5. Hasil inversi lintasan 7-1-6

Pada lintasan 7-1-6 terdapat lapisan soil yang bercampur dengan lapukan batugamping yang mengisi rekahan pada meteran ke-0 sampai $63 \mathrm{di}$ kedalaman 0-17 meter. Lapisan ini juga terdapat pada meteran ke-147 sampai 161 di kedalaman 017 meter. Lapisan ini terindikasi sebagai material timbunan. Material dominan pada lintasan ini berupa batugamping terumbu dan batugamping yang lebih kompak (massive).Pada lintasan ini juga terdapat indikasi goa/void batugamping dengan nilai resistivity $750-1500 \Omega \mathrm{m}$ dimulai pada meteran ke-154 sampai 203 dan mulai di kedalaman 5 meter. Hal ini berdasarkan pada korelasi antara hasil pengukuran dengan kondisi di lapangan, dimana pada ujung lintasan 7-1-6 merupakan daerah void/goa. Lintasan ini diperkirakan melalui 1 titik bor, yaitu titik bor Pier 9/1C.

Pada Gambar 6 menunjukkan bahwa lintasan 8-5-4 memiliki 5 susunan lapisan yaitu lapisan dengan nilai resistivity $0.00-50 \Omega \mathrm{m}$, merupakan lapisan soil bercampur lapukan batugamping yang terdapat di sepanjang lintasan dengan kedalaman bervariasi mulai dari 0-17 m. Lapisan dengan nilai resistivity 50-750 $\Omega \mathrm{m}$, diduga merupakan lapisan batugamping terumbu yang masih memperlihatkan adanya rongga yang terdapat di sepanjang lintasan pada kedalaman 0-17 m. Lapisan dengan nilai resistivity 750-2000 $\Omega \mathrm{m}$, diduga merupakan lapisan batugamping yang lebih kompak (massive) yang terdapat pada kedalamaan 0-17 m. Lapisan dengan nilai resistivity 750-1500 $\Omega \mathrm{m}$ diduga merupakan rekahan (void/goa) $[9,10]$ batugamping yang diperkirakan memiliki ukuran lebih dari 2 meter.Lapisan dengan nilai resistivity $\geq 2000 \Omega \mathrm{m}$, diduga merupakan lapisan batuan keras berupa marmer atau batuan intrusi yang terletak pada permukaan dan pada kedalaman lebih dari $14 \mathrm{~m}$. 
Pada lintasan 8-5-4 terdapat lapisan soil yang bercampur dengan lapukan batugamping yang mengisi rekahan pada meteran ke-25 di kedalaman 4-12 meter. Lapisan ini juga terdapat pada meteran ke-67 di kedalaman 0-14 meter. Lapisan ini terindikasi sebagai material timbunan. Pada lintasan ini juga terdapat indikasi goa/void batugamping dengan nilai resistivity 750-1500 $\Omega \mathrm{m}$ dimulai pada meteran ke-137 sampai 203 dan mulai di kedalaman 3-14 meter dan pada meteran ke-170 sampai 179 di kedalaman 5-14 meter. Hal ini berdasarkan pada korelasi antara hasil pengukuran dengan kondisi di lapangan. Lintasan ini diperkirakan melalui 2 titik bor, yaitu titik bor Pier 8 dan titik bor Pier 9/CL.

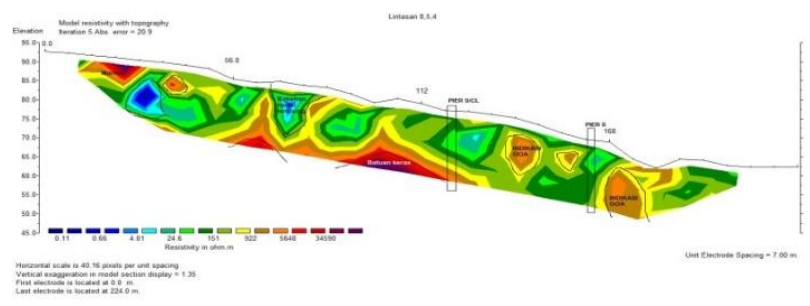

Gambar 6. Hasil inversi lintasan 8-5-4

Lintasan 9-2-3 yang ditunjukkan pada Gambar 7, memiliki 5 susunan lapisan yaitu lapisan dengan nilai resistivity 0.00-50 $\Omega \mathrm{m}$, merupakan lapisan soil bercampur lapukan batugamping yang terdapat di sepanjang lintasan dengan kedalaman bervariasi mulai dari 0-5 m. Lapisan dengan nilai resistivity 50-750 $\Omega \mathrm{m}$, diduga merupakan lapisan batugamping terumbu yang masih memperlihatkan adanya rongga yang terdapat pada kedalaman 0-17 m. Lapisan dengan nilai resistivity 750-2000 $\Omega \mathrm{m}$, diduga merupakan lapisan batugamping yang lebih kompak (massive) yang terdapat pada kedalamaan 5-17 m. Lapisan dengan nilai resistivity 750-1500 $\Omega \mathrm{m}$ diduga merupakan rekahan (void/goa) batugamping dengan ukuran sekitar lebih dari 2 meter. Lapisan dengan nilai resistivity $\geq 2000$ $\Omega \mathrm{m}$, diduga merupakan lapisan batuan keras berupa marmer atau batuan intrusi dengan kedalaman lebih dari $10 \mathrm{~m}$.

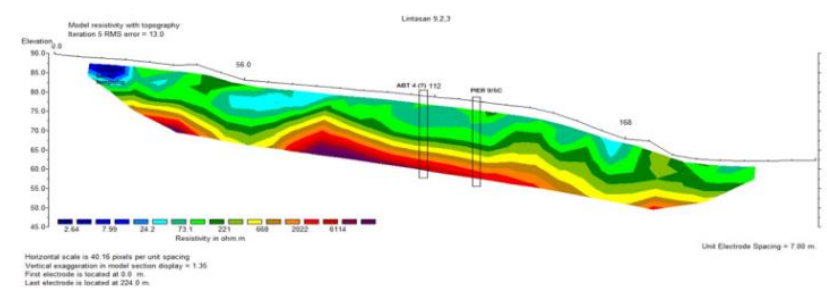

Gambar 7. Hasil inversi lintasan 9-2-3

Pada lintasan 9-2-3 terdapat lapisan soil yang bercampur dengan lapukan batugamping yang mengisi rekahan pada meteran ke-10 sampai 22 di kedalaman 0-5 meter. Lapisan ini terindikasi sebagai material timbunan. Pada lintasan ini material yang mendominasi berupa batugamping terumbu dan batugamping yang lebih kompak (masif).Lintasan 9-2-3 diperkirakan melalui 1 titik bor, yaitu titik bor BT 4 .

Berdasarkan hasil inversi menggunakan Res2DinV, maka lintasan geolistrik pada lintasan 10 sesuai Gambar 8 dapat di interpretasi bahwa lapisan dengan nilai resistivity 0.00-50 $\Omega \mathrm{m}$, merupakan lapisan soil bercampur lapukan batugamping yang terdapat di sepanjang lintasan dengan kedalaman bervariasi mulai dari 0-10 m. Lapisan dengan nilai resistivity 50-750 $\Omega \mathrm{m}$, diduga merupakan lapisan batugamping terumbu yang masih memperlihatkan adanya rongga yang terdapat pada kedalaman 0-17 m. Lapisan dengan nilai resistivity 750-2000 $\Omega \mathrm{m}$, diduga merupakan lapisan batugamping yang lebih kompak (massive) [1 , 9] yang terdapat pada kedalamaan 3-17 m. Lapisan dengan nilai resistivity 750-1500 $\Omega \mathrm{m}$ diduga merupakan rekahan (void/goa) batugamping dengan ukuran sekitar lebih dari 2 meter. Lapisan dengan nilai resistivity $\geq 2000$ $\Omega \mathrm{m}$, diduga merupakan lapisan batuan keras berupa marmer atau batuan intrusi dengan kedalaman mulai dari $5 \mathrm{~m}$.

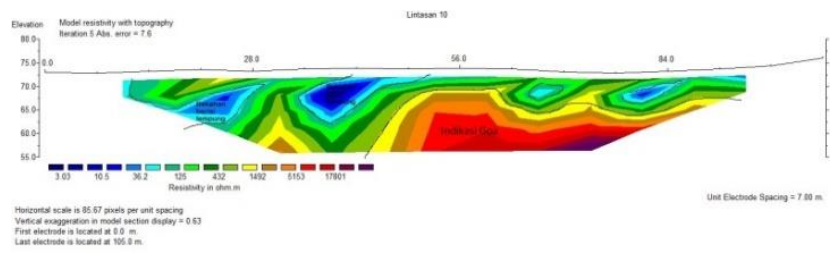

Gambar 8. Hasil inversi lintasan 10 
Lintasan 10 merupakan lintasan yang memotong ke-3 lintasan lain. Pada lapisan ini terdapat lapisan soil yang bercampur dengan lapukan batugamping yang mengisi rekahan pada meteran ke-11 sampai 30 di kedalaman 0-10 meter. Lapisan ini juga terdapat pada meteran ke35 sampai 53 di kedalaman 0-9 meter. Lapisan ini terindikasi sebagai material timbunan.Pada lintasan ini juga terdapat indikasi goa/void batugamping dengan nilai resistivity 750-1500 $\Omega \mathrm{m}$ dimulai pada meteran ke-43 sampai 94 dan mulai di kedalaman 3 meter.Hal ini berdasarkan pada korelasi antara hasil pengukuran dengan kondisi di lapangan.

\subsection{Korelasi dengan titik bor}

Berdasarkan data yang ada, terdapat 4 titik bor yang dilakukan sebelumnya sudah yaitu titik bor Pier 8, Pier 9/1C, Pier 9/CL dan Abutment 4. Namun, lokasi tepat dimana letak titik bor tersebut tidak pasti, karena penanda titik bor di lapangan sudah tidak ada akibat telah dimulainya pekerjaan konstruksi.Lokasi titik bor diperkirakan berdasarkan dari gambar layout lokasi pekerjaan seperti yang ditunjukkan pada Gambar 9.

Titik bor Pier 9/1C terletak pada lintasan 7-16 di sekitar meteran ke-119. Pada Gambar 10 corebox titik bor Pier 9/1C diketahui lapisan soil terdapat pada kedalaman 0-4 meter. Pada kedalaman 4-7 meter merupakan batugamping terumbu yang masih menunjukkan adanya rongga. Pada kedalaman 7-15 meter merupakan batugamping yang lebih kompak (massive).

Titik bor Pier 8 diperkirakan terletak pada lintasan 8-5-4 meteran ke-161. Pada Gambar 11 corebox titik bor Pier 8 diketahui lapisan soil terdapat pada kedalaman 0-1,5 meter. Pada kedalaman 4-12 meter merupakan batugamping terumbu yang masih menunjukkan adanya rongga. Dan pada kedalaman 12-15 meter merupakan batugamping yang lebih masif. Pada gambar corebox titik bor Pier 9/CL diketahui di kedalaman 0-8 meter merupakan batugamping terumbu yang masih menunjukkan adanya rongga. Pada kedalaman 8-15 merupakan batugamping yang lebih kompak (massive).

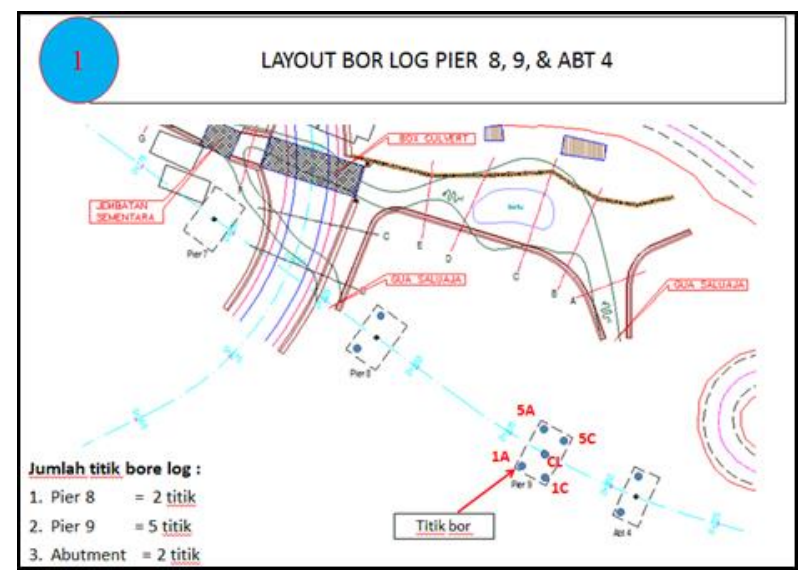

Gambar 9. Layout lokasi pekerjaan

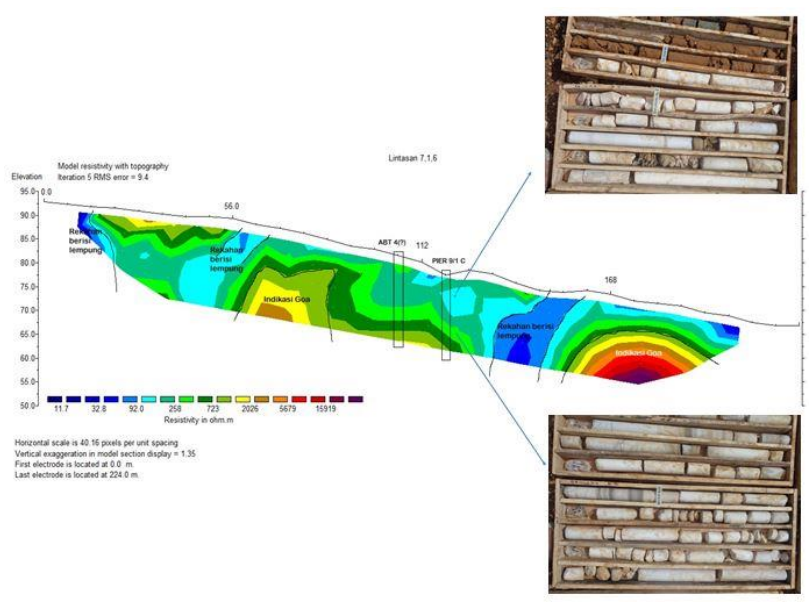

Gambar 10. Lokasi titik bor Pier 9/1C pada lintasan geolistrik 7-1-6

Titik bor Pier 9/CL diperkirakan terletak pada lintasan 8-5-4 meteran ke-120. Pada Gambar corebox titik bor Pier 9/CL diketahui lapisan soil terdapat pada kedalaman 0-1,5 meter. Pada kedalaman 2-9,6 meter merupakan batugamping terumbu yang masih menunjukkan adanya rongga. Dan pada kedalaman 9,6-15 meter merupakan batugamping yang lebih masif.

Titik bor ABT 4 diperkirakan terletak pada lintasan geolistrik 9-2-3 meteran ke-108. Pada Gambar 12 corebox titik bor ABT 4 diketahui lapisan soil terdapat pada kedalaman 0-2,7 meter. Pada kedalaman 2,7-7 meter merupakan batugamping terumbu yang masih menunjukkan adanya rongga. Pada kedalaman 7-15 meter merupakan batugamping yang lebih kompak (massive). 


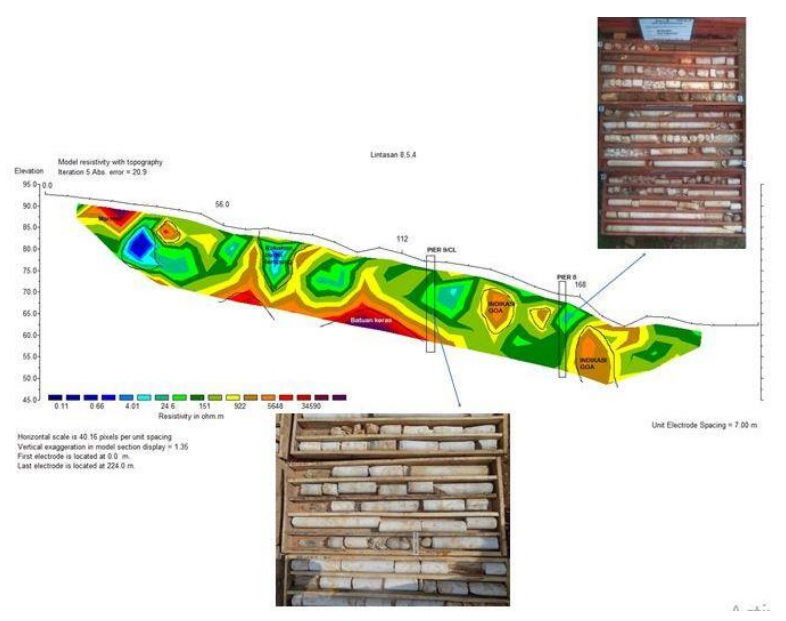

Gambar 11. Lokasi titik bor Pier 8 dan Pier 9/CL pada lintasan geolistrik 8-5-4

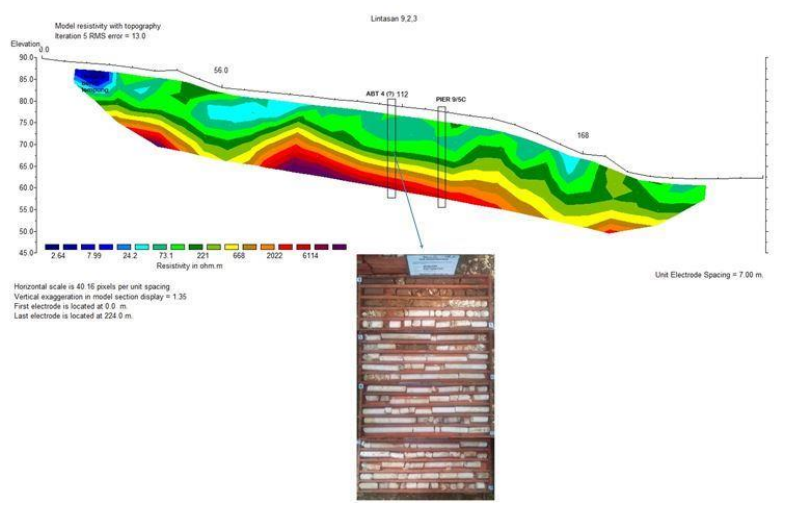

Gambar 12. Lokasi titik bor ABT 4 pada lintasan geolistrik 9-2-3

\section{Kesimpulan}

Dari pengukuran geolistrik dapat disimpulkan bahwa:

1. Hasil pengukuran arah memanjang dan melintang menunjukkan bahwa kondisi lapisan tanah terdiri atas lempung, lapukan batu gamping, batu gamping terumbu dengan rekahan dan rongga dengan ketebalan dan variasi mulai dari 2 hingga $10 \mathrm{~cm}$.

2. Hasil pengukuran geolistrik arah memanjang menunjukkan adanya indikasi keberadaan rogga dalam ukuran besar mencapai $2 \mathrm{~m}$ di sekitar pier 9 dan pier 8 . Selain itu terdapat rekahan yang diidentifikasi sebagai lempung lunak dan keberadaan air dalam rongga.

3. Perencanaa Pier 8 dan pier 9 yang berada tidak jauh dari indikasi keberadaan gua harus dipertimbangkan untuk dipindahkan posisinya ke tempat yang lebih stabil atau dilakukan grouting untuk mengisi perlemahan yang ada pada daerah tersebut.

\section{Ucapan Terimakasih}

Penulis mengucapkan terima kasih kepada bapak Ir. Budiamin, M.T selaku Kepala Bidang Peralatan dan Pengujian pada Balai Besar Jalan Nasional Wilayah VI Makassar yang telah memberikan peluang kerjasama dalam studi ini. Penulis juga mengucapkan terima kasih kepada bapak DR. Eng. Tri Harianto, S.T, M.T yang telah bekerjasama sebagai ketua tim dalam studi ini.

\section{Referensi}

[1] Luna.R and Jadi.H. 2000. Determination of dynamic soil properties using geophysical methods Proc. 1st Int. Conf. On the Application of Geophysical and NDT Methodologies to Transportation Facilities and Infrastructure Gephysics (Federal Highway Administration, Saint Louis, Mo) vol 3 pp 1-15.

[2] Othman, A.A.A. 2005 Construed geotechnical characteristics of foundation beds by seismic measurements. Journal Geophysics England. 2126-38.

[3] Lowrie, W. 2007. Fundamental of Geophysics (2nd ed.). New York: Cambridge University Press.

[4] Telford, W.M. 1990. Applied Geophysics. London: Cambridge University Prees.

[5] Soupios, P.M., Papazachos, C.B., Vargemezis, G and Fikos. I. 2005. Application of modern seismic methods for geotechnical site characterization Proc. Int. Workshop in Geoinvironment and geotechnics (Milos Island, Greece, 12-14 September) pp 163-70.

[6] Soupios, P.M., Papazachos, C.B., Vargamezis, G and Savvaidis, A. 2006. In situ geophysical investigation to evaluate dynamic soil properties at th Ilarionas Dam, Northern Greece Proc. 2nd Int. Conf. Advances in Mineral Resources Management and Environmental Geotechnology (Hania, Crete, Greece, 25-27 September 2006) (Helitopos Conferences) pp 149-56.

[7] Soupios, P.M., Georgakopoulos P, Papadopoulos N, Saltas V, Andreadakis A, Vallianatos F, Sarris A and Makris J.P. 2007. Use of engineering geophysics to investigate a site for a building foundation J. Geophys. Eng 4 94-103.

[8] Paulus. 2012. Pemodelan 3D Cavity Daerah " $X$ " dengan Menggunakan Metode Resistivity Konfigurasi Dipole-Dipole, Universitas Indonesia.

[9] Venkateswara, V.R., Srinivasa R, Prakasa R.B.S and Koteswara, R.P. 2004. Bedrock Investigation by seismic refraction method - a case study J. Ind. Geophysics. Union 8 pp 223.

[10] Klimis N.S, Papazachos C.B and Efremidis Ch F. 1999. Determination of the behavior of a sedimentary rock mass: comparison of measured static and dynamic properties proc. 9th Int. Conf. on Rock Mechanics (Paris, France). 